\title{
Why We Have No Theory of European Private Law Pluralism
}

\author{
Ralf Michaels, Duke Law School
}

Forthcoming in: Pluralism and European Private Law

(Leone Niglia, ed., Hart, 2013)

The recent popularity of legal pluralism has now reached the area of European private law. In this paper I scrutinize the concepts of legal pluralism used by three of its most prominent proponents: Pierre Legrand, Jan Smits, and Thomas Wilhelmsson. I do not offer fully-fledged criticism of their theories (each of which are among the most fascinating and helpful in the European private law debate) but only address their use of ideas of legal pluralism, and the relation of these ideas with the legal pluralism debate. My analysis shows not only that these three use sharply different concepts of legal pluralism, but also, that none of these three concepts is in accordance with traditional definitions of pluralism. Further, it turns out that several points of criticism can be raised against their theories that stem from the legal pluralism debate. I do not, here, take the second step of determining whether an actual concept of European private law pluralism can be established - and whether such a concept can withstand the criticism that has been voiced against the idea of legal pluralism.

Keywords: Legal pluralism, European private law

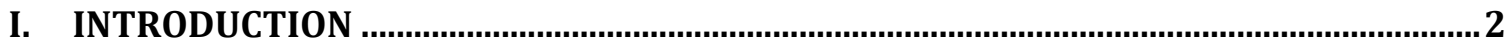

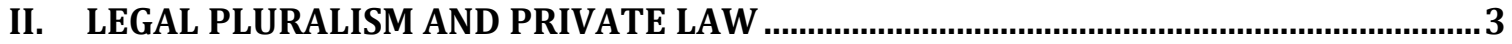

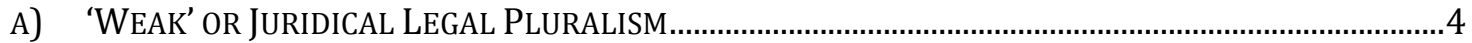

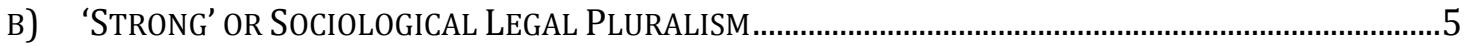

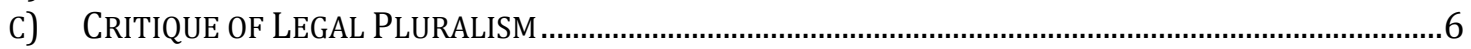

III. A COMMUNITARIAN PLURALISM - PIERRE LEGRAND ….............................................. 7

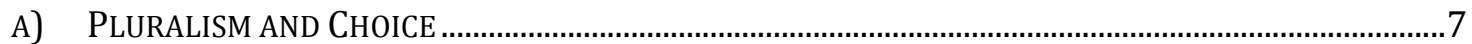

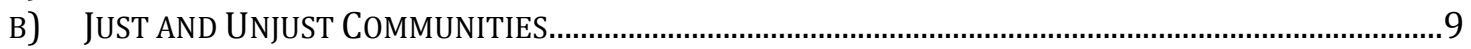

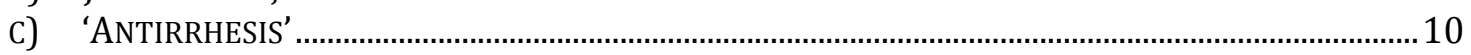

IV. A LIBERAL PLURALISM- JAN SMITS ........................................................................ 12

A) LEGAL PLURALISM AND CHOICE ……………………………………………………………....13

B) MANDATORY AND FACILITATIVE RULES .....................................................................................14

C) THE MARKETPLACE FOR RULES AND IDEAS ............................................................................15

V. A POSTMODERN PLURALISM - WILHELMSSON …….................................................16

A) EXTERnAL PluRALISM AND INTERNAL COHERENCE …………………………………………....18

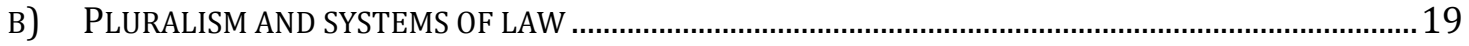

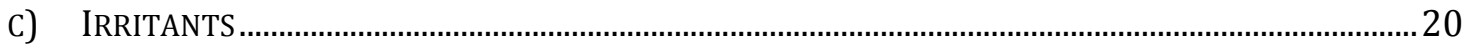

VI. CONCLUDING REMARKS .......................................................................................... 21 


\section{Introduction}

A significant part of the debates over European private law concerns the relations between the member state level and the European level. The substance of this debate has remained remarkably constant in since it arose some thirty years ago, despite the events that have taken place during that period: the growth of actual EU legislation in European private law; the formulation of a social alternative to the perceived market liberal private law ideal dominating in EU law, the simultaneous broadening and deepening of European integration, etc. Still, the basic question remains this: how much private law should be made (and unified) on a European level, how much law should remain within the member states, and how should the relations between European and domestic level be organized?

If the debates deal with the same substance, the terminology, however, has changed. For a long time, national European law was defended as an achievement of national identity and democratic legitimacy - the cultural value of national private law was a relevant factor, but it was usually defended as a subset of national law. ${ }^{1}$ Today, the European Union has significantly improved its democratic legitimacy and moved its own identity beyond that of a purely economic union. It is perhaps in response to these changes that defenders of national private law are now, more and more, invoking a new idea - that of legal pluralism. ${ }^{2}$ And indeed, some Europeanists are accepting the terminology and begin to argue against such legal pluralism. ${ }^{3}$

But legal pluralism is no invention by private lawyers-both the concept and the theory have spurred long discussions in legal anthropology, legal sociology, and legal theory. Although proponents of a European legal pluralism sometimes invoke these discussions, they tend to gloss over the precise way in which the concept is defined and defended in these debates, and they tend to ignore the backlash that has emerged against the concept in these disciplines. This is unfortunate. After all, the discussion provides rich experiences, both theoretical and empirical, on the interactions between legal orders. European private law could perhaps benefit from

\footnotetext{
${ }^{1}$ See R Michaels, 'Code vs Code: Nationalist and Internationalist Images of the Code civil in the French Resistance to a European Codification' (2012) 8 European Review of Contract Law _.

${ }^{2}$ In addition to the texts by Legrand, Smits and Wilhelmsson discussed below, see e.g. K Purnhagen, 'Principles of European Private or Civil Law? - A Reminder of the Symbiotic Relationship between the ECJ and the CFR in a Pluralistic European Private Law' European Law Journal (forthcoming); see already R Schulze, 'Pluralismus der Rechte in Europa' in HD Assmann et al (eds), Unterschiedliche Rechtskulturen-Konvergenz des Rechtsdenkens (Nomos, 2001).

${ }^{3}$ Eg B Akkermans, 'L'Europe, c'est nous' and the way forward...,' Mastricht European Private Law Blog at www.mepli.blogspot.com/2011/01/leurope-cest-nous-andway-forward.html (January 25, 2011).
} 
taking these debates into account; at least they may help throw new lights on existing debates.

In this paper I want to take a first, critical, step towards such an account. I want to scrutinize the concepts of legal pluralism used by three of its most prominent proponents: Pierre Legrand, Jan Smits, and Thomas Wilhelmsson. I do not offer fully-fledged criticism of their theories (each of which are among the most fascinating and helpful in the European private law debate) but only address their use of ideas of legal pluralism, and the relation of these ideas with the legal pluralism debate. My analysis shows not only that these three use sharply different concepts of legal pluralism, but also, that none of these three concepts is in accordance with traditional definitions of pluralism. Further, it turns out that several points of criticism can be raised against their theories that stem from the legal pluralism debate. I do not, here, take the second step of determining whether an actual concept of European private law pluralism can be established - and whether such a concept can withstand the criticism that has been voiced against the idea of legal pluralism.

\section{Legal Pluralism and Private Law}

The traditional concept of legal pluralism, developed in legal anthropology and sociology to analyze overlapping normative orders within societies, became popular in the 1970s and 1980s, though the phenomenon is much older. ${ }^{4}$ Although definitions of legal pluralism diverge on details, 5 there is a wide consensus that legal pluralism describes a situation in which two or more laws (or legal systems) coexist in (or are obeyed by) one social field (or a population or an individual). ${ }^{6}$ In this way, legal pluralism is opposed to what is called state centralism-a perceived monopoly of the state in making and administering law. The contribution of this concept to our understanding of law is, therefore, twofold: First, it suggests that normative orders not generated by the state can also be viewed as law. Second, as a consequence, it requires us to deal with the existence of, and interaction among, more than one legal order.

4 B Tamanaha, 'Understanding Legal Pluralism: Past to Present, Local to Global' (2008) 30 Sydney Law Review 375; L Benton, 'Historical Perspectives on Legal Pluralism' (2011) 3 Hague Journal on the Rule of Law 57.

5 For discussion, see F von Benda-Beckmann, 'Who's Afraid of Legal Pluralism?' (2002) 47 Journal of Legal Pluralism and Unofficial Law 37; W Twining, 'Normative and Legal Pluralism: A Global Perspective' (2010) 20 Duke Journal of International and Comparative Law 473.

6 R Michaels, 'Global Legal Pluralism' (2009) 5 Annual Review of Law and the Social Sciences 243, 245. 
In theory, the first aspect - non-state law - should be of specific interest to private lawyers. After all 'private' law has always been about both: law made for and law made by private parties. ${ }^{7}$ However, although some participants in the debates about European private law do include the first aspect and address the existence and role of non-state law in European private law, ${ }^{8}$ the focus on the debate on European private law pluralism is on the second aspect, that of plurality. This might suggest that what authors mean when they say pluralism is merely plurality, and therefore, debates on legal pluralism would not be helpful. I do not think this response is successful. If indeed the European discourse addresses merely the existence of a plurality of legal orders, without attention to their interaction, that discourse is incomplete and can benefit from the legal pluralism debate.

\section{a) 'Weak' or Juridical Legal Pluralism}

The first generation of legal pluralism, at least in this trajectory, was developed, especially by lawyers, in the colonial and postcolonial context. ${ }^{9}$ Colonies in Africa and Asia lacked the order of law in European states; they displayed somewhat unorganized laws that were deemed tribal, or customary law. Colonizing powers imposed their own law, while carefully leaving some space for this customary law that they found. Legal pluralism was then used as a tool to describe the ensuing plurality of interacting legal systems, and as a theory of their interaction. This type of legal pluralism is sometimes called 'juridical pluralism' because it was described mainly by lawyers, and it was also managed by specifically legal means - direct or indirect rule, ${ }^{10}$ hierarchical superiority rules, conflict-of-laws rules. ${ }^{11}$

\footnotetext{
${ }^{7}$ R Michaels and N Jansen, 'Private Law Beyond the State? Globalization, Europeanization, Privatization' (2006) 54 American Journal of Comparative Law 843. Cf. F Möslein, Dispositives Recht (Mohr Siebeck, 2011).

8 See e.g. J Smits, Private Law 2.0: on the Role of Private Actors in a Post-National Society (Hague Institute for the Internationalisation of Law, 2011) 8-9; ; Christian Joerges, 'A New Type of Conflicts Law as Constitutional Form in the Postnational Constellation' (2011) Transnational Legal Theory 153, 160. The most magisterial analysis (though not exclusively focused on Europe) is G Calliess and P Zumbansen, Rough Consensus and Running Code: A Theory of Transnational Private Law (Hart, 2010).

9 MB Hooker, Legal Pluralism (Oxford: Clarendon, 1975).

10 M Crowder, 'Indirect Rule: French and British Style' (1964) 34 Journal of the International African Institute 197.

11 RD Kollewijn, 'Conflicts of Western and Non-Western Law' (1951) 4 International and Comparative Law Quarterly 307; K Lipstein, 'Interpersonal conflict of laws' in International Encyclopedia of Comparative Law (Mohr Siebeck/MartinusNijhoff 1985); U Uche, 'Conflict of Laws in a Multi-Ethnic Setting: Lessons From Anglophone Africa' (1991) 228 Recueil des Cours 273.
} 
This concept of legal pluralism came under severe criticism. ${ }^{12}$ The main criticism was that a situation in which the state is still viewed as superior to other legal orders was no way to overcome state centralism. ${ }^{13}$ In some ways, it creates even an enhanced state centralism, because now state law sets out to define, and subordinate, even non-state normative orders. ${ }^{14}$ It was, in other words, 'weak' legal pluralism. Moreover, to subject non-state legal orders to the recognition by the state was considered oppressive: recognition should be a consequence of these orders' existence and their legal character, not its prerequisite. ${ }^{15}$ The exclusively legal perspective on legal pluralism was blamed for this situation; the exclusive focus on order was considered repressive.

\section{b) 'Strong' or Sociological Legal Pluralism}

An alternative to this 'weak' or juridical legal pluralism was sought and found in what is sometimes called 'strong' or sociological legal pluralism. This view takes legal pluralism as a fact of sociological observation, which demonstrates that individuals everywhere are governed by (or feel compelled by) a plurality of different, sometimes conflicting norms, only some of which emanate in the state. ${ }^{16}$ The sociological perspective also rejects clear rules describing the relation between the existing plural orders. Hierarchy is rejected, both on normative and on empirical grounds: hierarchy is not desirable to give hierarchy to state law and thereby reduce other laws to the status of subordination, but hierarchy is also not empirically true, because the relation between the different normative orders is under constant negotiation. Conflict of laws rules are also dismissed (in my view, a bit too hastily) ${ }^{17}$, either because such rules deny legal pluralism altogether (by allocating a distinct space to each of them) or because they provide an unduly technical and orderly way to deal with the interactions between legal orders. Instead, the idea of 'interlegality,' introduced by Boaventura de Sousa Santos, has proven popular.

This 'new' legal pluralism was not necessarily confined to the colonial and postcolonial context and has been made fruitful also for interactions between official and unofficial rules in Western legal systems.

${ }^{12}$ See especially, John Griffiths, 'What is Legal Pluralism' (1986) 24 Journal of Legal Pluralism and Unofficial Law 1.

${ }^{13}$ Griffiths, supra note 12 at 8.

${ }^{14}$ See also R Michaels, 'The Re-State-Ment of Non-State Law' (2005) 51 Wayne Law Review 1209.

${ }^{15}$ See also R Bolens et al, Legal Pluralism and the Politics of Inclusion: Recognition and Contestation of Local Water Rights in the Andes, in B van Koppen et al (eds) Community-based Water Law and Water Resource Management Reform in Developing Countries (CAB International, 2007) 96, 99-101.

${ }^{16}$ Griffiths, supra note 12 at 4 ('Legal pluralism is a fact. Legal centralism is a myth, an ideal, a claim, an illusion.').

${ }_{17}$ R Michaels, supra note 6, at 245 with references. See also now PS Berman, Global Legal Pluralism (Cambridge University Press 2012). 


\section{c) Critique of Legal Pluralism}

In recent years, the idea of legal pluralism, whether weak or strong, juristic or sociological, has come under severe criticism in legal sociology and anthropology. ${ }^{18}$ Notably (and importantly) the alternative proposed by the critics has not been legal monism. Their point was not to deny the plurality of law, but rather the way in which this plurality is conceptualized by proponents of legal pluralism.

Among the myriad of critical points, the following may be the most helpful for the debate on legal pluralism in Europe. First, ideas of legal pluralism, willingly or not, tend to prioritize, normatively, plurality over uniformity, without a clear justification. ${ }^{19}$ In the same realm, they prefer the local over the global, or, put differently, they tend to romanticize customary, non-state legal orders, while at the same time villifying the state. Second, studies of legal pluralism are often blind for power relations, both within and between legal orders: ${ }^{20}$ The emphasis on a plurality of legal orders underestimates the tendency of some of those to be far more powerful than others; the view of customary legal orders as 'black boxes' makes criticism of the content of customary law difficult to sustain. (This struggle plays out also in the debate between multiculturalism and basic rights, and the question whether the autonomy of groups should be recognized even if these groups themselves discriminate internally against their members.) Third, legal pluralism tends to essentialize legal orders-it assigns objective reality to them, whereas in reality such orders remain in constant flux, may change over time, develop both internally and in their relationship with other orders. ${ }^{21}$ Fourth, and relatedly, the idea of legal pluralism requires the possibility to distinguish between legal relations within a legal order and relations between legal orders; it must therefore assume relatively strong boundaries between legal orders, and a relatively high degree of consistency within legal orders. ${ }^{22}$ Fifth, legal pluralism, in its emphasis on legal orders as constraints, underestimates human agency. ${ }^{23}$

${ }^{18}$ For debate of much of this criticism by a proponent of legal pluralism see BendaBeckmann, supra note 5. For references for the following critique, see Michaels, supra note 6.

19 M Sharafi, 'Justice in Many Rooms Since Galanter: De-Romanticizing Legal Pluralism Through the Cultural Defense' (2008)71 Law \& Contemporart Problems 139.

${ }^{20}$ G Barzilai, ‘Beyond Relativism: Where is Political Power in Legal Pluralism?' (2008) 9

Theoretical Inquiries in Law 395.

${ }^{21} \mathrm{JF}$ Weiner, 'Eliciting customary law' (2006) Asia Pacific Journal of Anthropology 15.

${ }^{22} \mathrm{~S}$ Wastell, 'Presuming Scale, Making Diversity - On the Mischiefs of Measurement and the Global: Local Metonym in Theories of Law and Culture' (2001) 21 Critique of Anthropology 185.

${ }^{23}$ Jeremy Webber, 'Legal Pluralism and Human Agency' (2006) 44 Osgoode Hall Law Journal 


\section{A Communitarian Pluralism - Pierre Legrand}

My first example comes from Pierre Legrand, who has long advocated that the plurality of European legal systems is both desirable and insurmountable. Legrand is responsible for a university program on 'globalization and legal pluralism' at the Sorbonne, and frequently invokes ideas of legal pluralism for his opposition to convergence and unification of European private law. ${ }^{24}$ Here is an excerpt from his criticism of the Draft Common Frame of Reference project: 25

I need not even argue that legal pluralism is inherently good. It is enough for me to say that legal traditions and the diversity of forms of life-in-the-law they embody remain the expression of the human capacity for choice and self-creation and, as such, deserve to be respected as incorporating a vital aspect of social existence which helps to define selfhood. Legal communities and individuals within these communities deserve to be given their historical due. They are entitled to deep-level recognition. Indeed, they can demand recognition of their ontological identity but also of their positional identity; I have in mind, for instance, the common law's antirrhetic positioning vis-à̀-vis the civil law.

This is, clearly, a sociological (or cultural), not a juridical pluralism. And indeed, this brief passage sounds attractive enough. Yet, closer analysis reveals a number of problems and inconsistencies.

\section{a) Pluralism and Choice}

First, Legrand suggests that legal traditions must be recognized because they express 'the human capacity for choice and self-creation;' they incorporate 'a vital aspect of social existence which helps to define selfhood.' Legal traditions are, in other words, both the object of choice and its precondition. We, as individuals, should be free to choose our own legal tradition - say, that of English law-and not have some foreign tradition imposed on us-say, that of the civil law, or of a European civil code. And, at the same time, if we are denied our legal tradition, we are denied our own social existence and thereby the conditions necessary for meaningful choice.

Legal traditions are thus object and precondition of choice at the same time. This is not paradoxical, but it makes the role of choice certainly more complex than this seemingly simple quote suggests. Thus, on the one hand, Legrand does not here advocate the free choice of any legal tradition, that is, the idea of a law market, ${ }^{26}$

\footnotetext{
${ }^{24}$ See already P Legrand, 'Against a European Civil Code' (1997) 60 Modern Law Review 44, 53 ('The promotion of a European Civil Code effectively represents an attack on pluralism').

25 P Legrand, 'Antivonbar' (2005) 1 Journal of Comparative Law 13, 36, internal footnote omitted.

${ }^{26}$ EA O'Hara and LE Ribstein, The Law Market (Oxford University Press, 2009).
} 
where law becomes a mere product ${ }^{27} \mathrm{He}$ would view a law market as an undue imposition of the logic of economics, competition, and commensuration, on legal traditions. ${ }^{28}$ In his proposal, we are in fact allowed only to choose our own legal tradition. Indeed, Legrand has elsewhere suggested that we are so bound by our tradition that we cannot overcome it: a civil lawyer can never think like a common lawyers; he can never become anything else than what he is. ${ }^{29}$ This type of selfhood then, it seems, is the opposite of choice; it is a matter of fate. If this implies freedom, then it is at best the Hegelian idea of freedom as the insight into necessity. ${ }^{30}$

On the other hand, Legrand is certainly correct that we make our choice not in a vacuum but within the constraints and empowerments from our environment, including our culture and our legal tradition. True choice and true definition of selfhood are not possible without recognition of that environment, and that environment is an important factor for our choices. Legrand sides here with communitarian/post-Hegelian critics of liberalism, who point out that the self is not prior to its decisions. ${ }^{31}$

This preference for communitarianism is a possible position, although maybe not a watertight one. Amartya Sen, for example, has, without addressing Legrand or comparative law, suggested that our identities are a matter of our choice, not necessity. ${ }^{32}$ Moreover, Sen's idea of 'substantial' freedom is almost the opposite of Legrand's Hegelian insight into necessity: it is the maximization of real opportunities, which may have to be brought about by a change of the governance structure.

Legrand's views on the relation between choice and environment may be defensible. What seems odd, however, is his implicit assumption that that environment is necessarily, and unchangeably, given by a national legal tradition. This assumption is not implied by his communitarian allies-whereas Hegel, of course, indeed viewed the state as the highest order, communitarians in his succession like Taylor and Walzer have emphasized the importance of non-state communities and orders, and in fact their multiplicity. Arguably, our legal environment today, and the

27 Roberta Romano, 'Law as a Product: Some Pieces of the Incorporation Puzzle' (1985) 1 Journal of Law, Economics, and Organization 225; H Eidenmüller, 'The Transnational Law Market, Regulatory Competition, and Transnational Corporations' (2011) 18 Indiana Journal of Global Legal Studies 707. 28 P Legrand, 'Econocentrism' (2009) 59 University of Toronto Law Journal 215. ${ }^{29}$ P Legrand, 'European Legal Systems are not Converging' (1996) 45 International \& Comparative Law Quarterly 52, 78.

30 On the connection between Legrand's ideas and Hegel, see J Q Whitman, 'The NeoRomantic Turn' in P Legrand \& R Munday (eds) Comparative Legal Studies:

Traditions and Transitions (Cambridge University Press, 2003) at 316.

${ }^{31}$ See e.g., M Sandel, Liberalism and the Limits of Justice (Harvard University Press, $2 \mathrm{~d}$ ed. 1998); Charles Taylor, Sources of the Self: The Making of Modern Identity (Harvard University Press, 1989); M Walzer, Spheres of Justice: A Defense of Plurality and Equality (New York: Basic Books, 1983).

${ }^{32}$ A Sen, Reason Before Identity (Oxford University Press, 1999). 
conditions of our choices, are also already made up of a cacophony of norms and laws, some of which are from foreign legal traditions or from supranational law or from nonstate normative orders like religion. Legrand's view, that we are influenced only by one legal tradition, be it civil of common law, actually appears to suppress such difference. This is no novelty: legal pluralism in this sense characterized both the common law and the civil law since times immemorial. ${ }^{33}$ But although Legrand acknowledges the existence of differences within legal traditions, he clearly views them as secondary, ${ }^{34}$ and they play no role for his analysis. ${ }^{35}$

\section{b) Just and Unjust Communities}

Let me move to another point. Legrand suggests that 'legal communities and individuals within these communities deserve to be given their historical due.' We may wonder what 'their historical due' is exactly, but it seems to be something. But in what sense is this not an is/ought cross-over? Why does a legal tradition deserve recognition merely because it exists?

This is a problem that permeates discussions in legal pluralism, too: cultures and traditions are viewed as deserving protection merely because they exist. This sounds attractive, but it is not at all obvious. The mafia culture is cruel; is it nonetheless worthy of protection merely because it is a culture? It may be paternalistic to try and eradicate cultures merely for the sake of unity, but is it not similarly paternalistic to want to protect and defend cultures and traditions merely for the sake of their existence?

The biggest problem, however, lies elsewhere: It is fine to recognize communities and individuals, but what if there is a conflict between what legal communities are due and what individuals within these communities are due? This is the issue brought to the fore in Susan Moller Okin's now famous powerful question whether multiculturalism is bad for women, because the cultural groups that we recognize may themselves be discriminatory. ${ }^{36}$ In such a case, arguably, we can either recognize fully the community or the individual but not both, and it is not obvious

\footnotetext{
${ }^{33}$ For the common law, see HW Arthurs, Without the Law: Administrative Justice and Legal Pluralism in Nineteenth Century England (University of Toronto Press, 1985); L Sheleff, The Future of Tradition: Customary Law, Common Law, and Legal Pluralism (2000); GR Woodman, 'The involvement of English common law with other laws' in C Eberhard and G Vernicos (eds) La quête anthropologique du droit: Autour de la démarche d'Etienne Le Roy (Editions Karthala, 2006), 477. For the civil law, see B Tamanaha, supra note 4, at 377-81; J Tontti , European Legal Pluralism as a Rebirth of Jus Commune, (2001) 24 Retfaerd Nord 40.

${ }^{34}$ E.g. Legrand, supra note 29, at 63

${ }^{35}$ Cf. Geoffrey Samuel, Epistemology and Method in Law (Ashgate 2003) 50 note 141.

${ }^{36}$ S Moller Okin, Is Multiculturalism Bad for Women? (Princeton University Press 1999).
} 
which of them should take priority. ${ }^{37}$ The mere idea of ('deep') recognition, which Legrand borrows from Michael Walzer, does not seem to help; it is precisely in response to the emphasis on recognition (by Walzer and others) that Okin's challenge and the ensuing debate arose.

These questions are, at least prima facie, relevant also to private law. Private law has traditionally been viewed as freedom-enhancing, but there is little doubt that it can also be constraining. ${ }^{38}$ Same-sex couples who cannot get married under Irish law are an obvious example. consumers who are barred from purchasing certain products are another, but of course, so are consumers who are stuck, under doctrines of freedom of contract, with destructive mortgage contracts. The communitarian argument may still succeed if it can be shown that the best way to improve the individual's situation lies within the respective legal system-in other words, although private law systems may be different, and differently unjust, they each provide the best opportunities for improvement internally. This would be plausible if indeed freedom and embeddedness within one's legal tradition were inseparably linked-the argument discussed in the previous section. Many individuals, however, seem to disagree-they opt out of their own legal systems.

Christian Joerges has made a powerful counterproposal to Legrand's suggestion that recognition of the individual and her legal order are the same. In his view, one of the most important functions of European law is that it enables the individual to require her own government to justify its actions. ${ }^{39}$ Here, the alternative is not between recognizing the legal order and recognizing the individual. Rather, the idea is for European law to intervene in the relation between the individual and her society and empower her, to some extent and under certain conditions, vis-à-vis the legal order. Legrand would probably reject such types of intervention because of the violence they commit against a legal culture that deserves protection, but he does not tell us why injustice against a legal order must necessarily be more important than injustice against an indivudal.

\section{c) 'Antirrhesis'}

Finally, it is worth analyzing 'the common law's antirrhetic positioning vis-à-vis the civil law.' 40 Legrand borrows the idea of antirrhesis from Peter Goodrich, who in turn finds it in theological rhetoric. Antirrhesis is, according to Henry Peacham, 'a

37 This is a simplified discussion; for detail, see K Knop, Ralf Michaels \& Annelise Riles, 'From Multiculturalism to Technique: Feminism, Culture and the Conflict of Laws Style' (2012) 64 Stanford Law Review 589, 596-609.

38 The classical argument is RL Hale, 'Coercion and Distribution in a Supposedly Non-Coercive State' (1923) 38 Political Science Quarterly 470,.

${ }^{39} \mathrm{C}$ Joerges, 'On the Legitimacy of Europeanising Private Law: Considerations on a Justice-making Law for the EU Multilevel System"' (2003) 7:3 Electronic Journal of Comparative Law 7:3, http://www.ejcl.org/73/art73-3.html;

${ }^{40}$ Legrand has made this argument earlier; see P Legrand, 'The same and the different' in P Legrand and R Munday (eds), Comparative Legal Studies: Traditions and Transitions (Cambridge University Press, 2003), 240, at 244-5. 
form of speech by which the orator rejecteth the authority, opinion or sentence of some person: for error or wickedness of it ... this form of speech doth especially belong to confutation and is most apt to repell errors and heresies and to reject evil counsell and lewd perversions. ${ }^{41}$ What is at stake here, is, in other words, the violent refutation of an argument. As such it appears to be, if anything, the very opposite of the recognition that Legrand proclaims.

It seems questionable whether such antirrhesis really describes, in an objective sense, the view the common law takes of the civil law. Goodrich himself does argue this, but mainly in the context of debates in sixteenth century England: 'the rule of the parent civil law is a trauma for a common law which seeks its own identity through separation, antirrhetic, and polemic. 42 This describes a particular point in time-the fight of protestants against catholics (who represented the civil law). It is not obvious why this historical precedent of antirrhesis must invariably still be valid today - or why this particular view of the rhetorical element in the common law, found in the common law, should be unavoidable for modern (or postmodern) legal anslysis. ${ }^{43}$

For comparative law purposes, another thing is even more important. We should recall that the violent refutation in question here was not directed against the civil law as the external other, but first and foremost against the heretics within English law. ${ }^{44}$ The problem was not, in other words, that the civil law was irremediable alien to the common law but, rather, that it was threatening to take over English law from within. Or, put differently, the fight between common law and civil law was a fight within an English law that was itself pluralistic in nature. Legrand's own frequent point that the common law is incommensurable with the civil law is itself a rhetorical move, a claim not for empirical truth but a position.

Whether, then, the common law is really antirrhetic vis-à-vis the civil law, is a matter of viewpoint, perhaps also of empirics. What seems clear, however, is that antirrhesis is a consequence not of incommensurability but, quite to the contrary, is one (extreme) position taken in response to the threat of actual commensurability. This means that this is only one possible position that legal traditions can take vis-àvis each other, and it is not even the one that Legrand himself seems to prefer. The normative problem is that antirrhesis represents precisely the violence against the other that Legrand otherwise deplores.

The trouble with Legrand's theory, then, is twofold. On the one hand, he commits to a number of ideas that are in accordance with legal pluralism but that have been

${ }^{41} \mathrm{H}$ Peacham, The Garden of Eloquence (H. Jackson, 1593), sig. N iv b-N v a; cited after P Goodrich, 'Antirrhesis. Polemical Structures of Common Law Thought' in A Sarat and TR Kearns (eds), The Rhetoric of Law (1995) 5, 59.

42 P Goodrich, Oedipus Lex: Psychoanalysis, History, Law (University of California Press, 1995) 160.

${ }^{43}$ Cf R Weisberg, 'Response to Goodrich on the Antirrhetic' (1992) 4 Cardozo Studies in Law and Literature 237, 238.

${ }^{44}$ Cf Goodrich 207. 
shown to be problematic. On the other hand, it is questionable whether his theory is one of legal pluralism at all. If legal pluralism depicts 'the coexistence of several normative orders in the same social field' then Legrand's depiction is not legal pluralism, because he denies, or at least downplays, the existence of the very social field in question: for him, legal traditions exist in neatly distinct fields. This is quite a powerful limitation of his theory, because it is the very interpenetration of legal orders that creates the question. Moreover, although he sometimes denies this, ${ }^{45}$ one underlying assumption seems to be of legal cultures that are conceived of as unrealistically unchangeable.

\section{IV.A Liberal Pluralism- Jan Smits}

Such criticism may not be apt against Jan Smits's recent development of legal pluralism as a helpful approach for European private law. ${ }^{46}$ The plurality of laws that Smits has in mind is not just, as in some of his earlier work, that of the member state laws. Rather, Smits argues that the nation state can no longer be viewed as the exclusive source of private law, nor can its democratic procedures be viewed as the sole source of legitimacy for private law norms. ${ }^{47} \mathrm{~A}$ plurality of sources existssome national, some European, some non-state-and the multiple sources overlap (have, as he puts it, 'an equal claim to validity'48) and stand in no clear hierarchical relation that could establish priorities. As a consequence, it becomes questionable whether private law is still 'a system.' Smits argues that such pluralism should neither be eliminated-through uniformisation or through top-down allocation by means of private-international-law rules-nor managed on the basis of some overarching policy, as in the Open Method of Coordination. Rather, plurality should be encouraged. Borrowing from literature on legal pluralism, Smits argues that people can feel a sense of belonging to several groups and being bound to their rules,

${ }^{45}$ Legrand himself distances himself from claims for internal coherence of either the civil or the common law tradition: P Legrand, supra note 40 at 244. His argument, however, seems to rest on such an assumption.

${ }^{46} \mathrm{~J}$ Smits, 'Plurality of Sources in European Private Law, or: How to Live With Legal Diversity?,' in Brownsword et al. (eds), The Foundations of European Private Law (Hart Publishing 2011) 323; J Smits, 'A Radical View of Legal Pluralism' in this volume

47 On this point also J Smits, 'European Private Law and Democracy-A Misunderstood Relationship' in M. Faure and F Stephen (eds), Essays in the Law and Economics of Regulation in Honour of Anthony Ogus (Oxford Intersentia, 2008) 49. ${ }^{48} \mathrm{~J}$ Smits, 'The Complexity of Transnational Law: Coherence and Fragmentation of Private Law' (2010) 14:3 Electronic Journal of Comparative Law, 10, http://www.ejcl.org/143/abs143-14.html. . 
so they should be able to choose the laws applicable to them. The consequence would be the decline of private law as a coherent system and of equal treatment, but these are not urgent problems once we conceive of law as a market. ${ }^{49}$

Note several ways in which Smits' conception of legal pluralism is opposed to that of Pierre Legrand. Other than Legrand, Smits proposes a juridical pluralism. However, where Legrand, like juridical pluralists, speaks of several incompatible but internally largely homogenous legal traditions (as expressed in national legal systems), Smits, seemingly like sociological pluralists, emphasizes the hybridity of the emerging law. Where Legrand essentially claims that individuals belong firmly to one tradition only, Smits emphasizes their plural affiliations. As a consequence, where choice for Legrand means the ability to make one's tradition one's own; for Smits it means the possibility to switch between different traditions and their laws.

\section{a) Legal Pluralism and Choice}

This use of choice is an ingenious twist on traditional ideas of communities. In much of the literature on legal pluralism, belonging to numerous communities is a matter not of choice but of necessity: a London-born Muslim may feel both as an Englishman and as a Muslim, but neither identity is a matter of choice for him, and the ensuing conflict between English and Islamic rules may feel more like a tragic choice ${ }^{50}$ than like the opportunity that Smits paints. Arguably, then, Smits' pluralism is not in accordance with traditional legal pluralism, but rather its opposite - Smits now calls his a 'radical view of legal pluralism' 51 . The trader in the law market is the opposite of the community-bound individual that many legal pluralists have in mind: individuals are able to choose among different laws not because they feel bound by all of them (as legal pluralists would argue) but because they feel bound by none of them. Law, for them, becomes a matter not of culture and tradition but instead a commodity 52 .

Smits, knowingly or not, adopts, in his concept of legal pluralism, a powerful critique of legal pluralism, namely that it does not allow for individual agency. ${ }^{53}$ Some legal pluralists have made a similar step: they now emphasize the empowering potential of legal pluralism, which enables in particular members of minorities to alter, strategically, between the invocation of different rules for their interest-state rules, local rules, and global rules (especially human rights rules). ${ }^{54}$ His ideas are thus

\footnotetext{
${ }^{49}$ Smits invokes O’Hara \& Ribstein, supra note 26.

50 On the inability of economic analysis to account for tragic choices, see M Nussbaum, 'The Costs of Tragedy: Some Moral Limits of Cost-Benefits Analysis' (2000) 29 Journal of Legal Studies 1005.

51 In this volume.

52 See supra note 27.

53 Supra note 23.

54 SE Merry, Human Rights and Gender Violence: Translating International Law into Local Justice (University of Chicago Press, 2006); B Rajagopal, "The Role of Law in
} 
comparable to those of Joerges mentioned before: the individual uses pluralism to escape laws and require them to justify themselves.

\section{b) Mandatory and Facilitative Rules}

Somewhat surprisingly, however, Smits does not go all the way, and his 'radical legal pluralism' is, in the end, anything but radical. Smits limits party choice to facilitative rules. This makes it necessary to distinguish facilitative from mandatory rules, as Smits points out, but he does not tell us how the distinction should be made or, more importantly, who should make it. (He does not, unfortunately, make use of the ample literature in choice of law on the question.) ${ }^{55}$

This limitation to facilitative rules is in opposition to neoliberal theories of conflict of laws. ${ }^{56}$ Here, proponents of a market for laws see its biggest attraction in the possibility for individuals to opt out of otherwise mandatory rules of one legal system by choosing another. Taking away that choice robs the approach of much of its neoliberal appeal. It goes behind even existing law, which allows parties to avoid most mandatory rules of the normally applicable law by choosing another law, and only protects so-called internationally mandatory rules against the party choice. ${ }^{57}$

However, leaving mandatory rules untouched will also leave legal pluralists unsatisfied. Facilitative rules are already widely subject to party autonomy under existing private law; insofar Smits only states the status quo. By contrast, the main focus of legal pluralists is precisely on situations in which actors face conflicting rules all of which claim applicability, and this is the difficult case. What about he Muslim who wants to comply with both religious and state law requirements? What to make of mandatory rules and the conflicts between them? Smits rightly argues, in accordance with both private international law scholars ${ }^{58}$ and legal pluralists ${ }^{59}$, that territoriality no longer serves as a good criterion. But he (like them) does not give us

Counter-hegemonic Globalization and Global Legal Pluralism: Lessons from the Narmada Valley struggle in India' (2005) 18 Leiden Journal of International Law 345. 55 See R Michaels, 'Die Struktur der kollisionsrechtlichen Durchsetzung einfach zwingender Normen' in R Michaels \& D Solomon (eds), Liber amicorum Klaus Schurig (Sellier 2012) 191.

56 MJ Whincop and ME Keyes, 'Statutes' Domains in Private International Law: An Economic Theory of the Limits of Mandatory Rules' (1998) 20 Sydney Law Review 435; EA O’Hara, 'Opting Out of Regulation: A Public Choice Analysis of Contractual Choice of Law' (2000) 53 Vanderbilt Law Review 1551.

57 R Michaels (supra note 55).

58 EG Lorenzen, 'Territoriality, Public Policy and the Conflict of Laws' (1923) Yale Law Journal 736; H Muir Watt, On the Waning Magic of Territoriality in the Conflict of Laws, in M Andenas and D Fairgrieve (eds), Tom Bingham and the Transformation of the Law: A Liber Amicorum (Oxford University Press, 2009) 751. 59 PS Berman, The Globalization of Jurisdiction' (2002) 151 University of Pennsylvania Law Review 311. 
any clearer answers ${ }^{60}$ than his hope for a legal doctrine that will move towards arguments. ${ }^{61}$

\section{c) The Marketplace for Rules and Ideas}

The hope is that the legal system will evolve, and the better rules, the better ideas will succeed. Here, Smits takes up his earlier ideas of a 'free movement of legal rules,' 62 an idea in turn inspired by (again neoliberal) concepts of regulatory competition, and combines it with a Habermasian hope in the 'unforced force of the better argument'. 63 This faces two important kinds of criticism.

First, this looks, in the end, more like a monist than a pluralist theory. In the competition for legal rules, the best one ultimately wins, and we have unity. ${ }^{64}$ In the Habermasian discourse, the better argument wins in the end, what we have is a tendency toward consensus and thus unity. ${ }^{65}$

Second, the hope that legal evolution will, somehow, lead to victory of the better argument presumes a rather perfect ('herrschaftsfrei') market for those ideas, and no interventions from special interests. It thus runs up against a criticism, which, from the opposite side, has been made against theories of legal pluralism, too: blindness to power relations. ${ }^{66}$ In legal pluralism, the almost romantic fascination with intersystemic dialogue and mutual deference sometimes tends to be blind to the role of power in determining winners and losers. Fascination over the fact that state law can never fully overcome non-state law but is instead influenced by it, makes some legal pluralists blind to two possibilities: First, the state may sometimes be 'cunning;' it may pretend to be weak in order to avoid responsibility for outcomes. ${ }^{67}$ Second, whether state law or non-state law wins, in a given conflict,

${ }^{60} \mathrm{Cf}$ the suggestions in R Michaels, Territorial Jurisdiction after Territoriality, in PJ Slot \& M Bulterman (eds), Globalisation and Jurisdiction (Kluwer International 2004) 105.

61 For Smits' own suggestions on the role of legal argument more general, see now his impressive book The Mind and Method of the Legal Academic (Elgar 2012). 62 J Smits, 'A European Private Law as a Mixed Legal System. Towards a Ius Commune through the Free Movement of Legal Rules' (1998) 5 Maastricht Journal of European and Comparative Law 328.

63 E.g. Jürgen Habermas, The Philosophical Discourse of Modernity: Twelve Lectures (MIT Press 1987) 130.

${ }^{64}$ Cf. J Smits, 'Mixed Jurisdictions: Lessons for European Harmonisation?' (2008)

12.1 Electronic Journal of Comparative Law.

${ }^{65}$ C Mouffe, 'Deliberative democracy or agonistic pluralism?' (1999) 66 Social Research 745.

66 Supra note 20.

67 S Randeria, 'The State of Globalization: Legal Plurality, Overlapping Sovereignties and Ambiguous Alliances between Civil Society and the Cunning State in India' (2007) 24 Theory, Culture and Society 1. 
allows no a priori conclusion for whether the concrete result of that victory is desirable or not. The same seems true for a marketplace of legal ideas: some ideas win because they were favored by those powerful or numerous enough to make that happen, but that does not say much about their intrinsic quality.

In the end, an umpire seems to be needed. Smits indeed finds such an umpire in the nation state and its lawmaker, who can (and, as he says, should) make clear which of its rules are mandatory (and thus exempt from party choice) and which are not.68 This preference for statutory determination of mandatory rules is shared in the literature on private international law. ${ }^{69}$ But it weakens considerably the pluralist idea of moving beyond state centralism.

\section{A postmodern pluralism - Wilhelmsson}

Yet a different concept of legal pluralism emerges from the work of Thomas Wilhelmsson. ${ }^{70}$ Wilhelmsson aligns himself with postmodernism, ${ }^{71}$ and it is therefore no surprise that he finds influence in the ideas about legal pluralism voiced by Boaventura de Sousa Santos. ${ }^{72}$ Wilhelmsson's starting point is one that is prominent in (though not exclusive to) postmodernism: contemporary societies are intrinsically, and irreducibly pluralistic. This is the case on the European level and on the national level. As a consequence, Wilhelmsson's legal pluralism operates at two levels: between, and within national legal systems.

As concerns pluralism between national legal systems, Wilhelmsson suggests (insofar like Legrand) that different legal systems rest on very different cultures and value systems. If this is so, then a static European unification would not be merely technical; it would also disrupt grown national and local structures and cultures of law. Wilhelmsson is here thinking less of the common law (which is Legrand's main focus) and more of Nordic law with its purported greater emphasis on informality and on social values..$^{73}$ In particular, he points out, the German Civil Code (BGB) does

68 Smits (supra note 76) 335..

69 O’Hara \& Ribstein, supra note 26.

70 In what follows, I can unfortunately only draw on publications in English.

${ }^{71}$ E.g. T Wilhelmsson, 'Towards a (Post)modern European Contract Law' (2001) 6 Juridica International 23. But cf. T Wilhelmsson, 'The ethical pluralism of late modern Europe and codification of European contract law' in J Smits (ed) The Need for a European Contract Law-Empirical and Legal Perspectives (Europa Law Publishing 2005), 125 (preferring late-modern over postmodern).

72 E.g. T Wilhelmsson, Critical Studies in Private Law - A Treatise on Need-Rational Principles in Modern Law (Springer, 1992), 224-226. Santos prefers to speak of legal plurality, largely because he opposes elements in the legal pluralism debate. Cf B de Sousa Santos, Toward a New Legal Common Sense (Butterworths, 2d ed. 2004), 8998.

73 T Wilhelmsson, supra note 72, at 16-20 et passim; T Wilhelmsson, Social Contract Law and European Integration (Dartmouth Publishing Company 1995), 7-11,191- 
not provide a helpful model for a European codification, because ' $[\mathrm{t}]$ he BGB was made for a bourgeois society and for $\mathrm{a}[\mathrm{n}]$ original market capitalism and in that sense could reflect a fairly homogeneous world outlook. ${ }^{74}$ Our world is different; we face a 'dissolution of traditional structures of understanding' and therefore an ethical fragmentation that can no longer be captured by a coherent code..$^{75}$ Wilhelmsson's plea for a 'fragmentized Europeanization'76 realises that even if Europe retains a plurality of national legal systems, it is important to focus somehow on the interrelation between these.

However, unlike Legrand, Wilhelmsson does not treat national legal systems as relatively coherent and autonomous. Instead, he emphasizes also the internally pluralistic character of national legal systems. The same dissolution also functions on the level of the state. The state becomes fragmented internally - different authorities attain semi-autonomy and will thus not always apply the same law the same way. But the state also becomes fragmented externally: 'the borderline between state and society becomes less and less clear'77 (an aspect that Wilhelmsson does not, as far as I can see, discuss at great length elswhere.

And, furthermore, Wilhelmsson even welcomes - to some extent - the mutual irritation between different laws. He shares Smits' preference for a free transfer of legal rules and ideas, ${ }^{78}$ though with less sympathy for an actual market that would generate such a transfer. What he calls a 'Jack-in-the-box' theory of European law is the idea that European law suddenly pops up within domestic legal systems in unexpected situations..$^{79}$ This creates disruptions in the national legal systems, but such disruptions can in fact be useful to break up old structures and traditions.

208. An interesting 'outsider's' analysis is J Smits, 'Nordic Law in a European Context: Some Comparative Observations' in J Husa et al (eds.), Nordic Law Between Tradition and Dynamism (Intersentia 2007) 55.

${ }^{74} \mathrm{~T}$ Wilhelmsson, 'Ethical pluralism' (supra note 71) 121.

75 See ibid 136; 'Contextual morality is difficult to connect with a general civil code with a strong systematic structure;' cf. T Wilhelmsson, Welfare State Expectations, Privatisation and Private Law, in T Wilhelmsson and S Hurri (eds) From Dissonance to Sense: Welfare State Expectations, Privatisation and Private Law (Ashgate, 1999) 3, 18-22. Andrei Marmor has made a somewhat related argument from a Rawlsian liberal perspective: our pluralism of ultimate conceptions of the good suggests that legislative coherence is not of high value: Andrei Marmor, Should we Value Legislative Integrity?, in Andrei Marmor, Law in the Age of Pluralism (Oxforud University Press, 2007) 39.

${ }^{76}$ T Wilhelmsson, 'Private Law in the EU: Harmonised or Fragmented Europeanization?' (2002) 1 European Review on Private Law 77, 89 ff.

$77 \mathrm{~T}$ Wilhelmsson (supra note 72) 224.

$78 \mathrm{~T}$ Wilhelmsson, supra note 74, at 124.

79 T Wilhelmsson, 'Jack-in-the-box theory of European Community law', in: L Krämer et al (eds), Law and Diffuse Interests in the European Legal Order: Liber Amicorum Norbert Reich (Nomos, 1997), 177; T Wilhelmsson, 'Private Law in the EU: Harmonised or Fragmented Europeanization?' (2002) 1 European Review on Private Law, 79-82. 
In many ways, Wilhelmsson's concept of legal pluralism is the one closest to strong or sociological legal pluralism as discussed above - and thus, many problems of his approach are problems of the whole idea of legal pluralism. In what follows, I want to focus on three problems with the conception that stem not from this proximity but from what I perceive as problems with Wilhelmsson's concept.

\section{a) External Pluralism and Internal Coherence}

A first problem is one that we already saw in Legrand's concept: the problem of internal homogeneity and essentialism. If pluralism is about plurality of legal systems, then it implies that differences between such systems are greater than differences within such systems - and thus, that systems themselves are relatively coherent internally. This is unproblematic for a communitarian concept; indeed, it might be considered a founding element of communitarianism. It is, however, diametrically opposed to the postmodern idea that Wilhelmsson espouses, namely, that legal systems are internally fragmented, too. ${ }^{80}$

And yet, when Wilhelmsson espouses a specific Nordic approach to law, he arguably falls into this trap of homogeneity. ${ }^{81}$ The idea that Nordic law has certain characteristics has become hugely popular in Nordic countries. ${ }^{82}$ But it presumes that there is something typically and (relatively) homogenously Nordic about law in Nordic countries. Moreover, if indeed law and society are as closely interconnected as Wilhelmsson suggests, then this presumes also that there is something typically and (relatively) homogenous about Nordic society. And this seems unavoidable. The stronger our claim that differences exist between the national systems of the EU, the more necessary it becomes that these legal systems are internally relatively coherent. The stronger external plurality thus implicates an internal homogeneity. ${ }^{83}$

Both these claims are problematic not only methodologically, but also factually. Rasmus Goksor shows in his forthcoming Duke dissertation how much the idea of a Nordic, or Scandinavian, identity is more a product of the $19^{\text {th }}$ and $20^{\text {th }}$ century than an essential trait of Scandinavia per se. And he demonstrates in that dissertation (as he has in an earlier publication $)^{84}$ that the idea of a specifically 'social' character of Nordic law, as compared to a hard liberal European law, is more complex than is usually acknowledged. Scandinavian law, like the law of any other country or region,

\footnotetext{
80 Supra note 21.

81 E.g. T Wilhelmsson, Social Contract Law and European Integration (Dartmouth 1995) 7.

82 See, most recently, Pia Pia Letto-Vanamo, Law and (Social) Justice - Nordic Perspectives (2011), http://ssrn.com/abstract=1823386.

83 This is so for most legal pluralists, though some, and especially postmodern pluralists, recognize the problem and suggest alternatives, like for example fractalized rather than plural law.

84 R Goksor, 'Jurisprudence on Protection of Weaker Parties in European Contract Law From a Swedish and Nordic Perspective' (2006) 6 Chicago-Kent Journal of International \& Comparative Law 184.
} 
emerges from numerous internal struggles that remain infinitely unresolved, and 'social' ideas struggle with more market liberal ones. Scholars often take Wilhelmsson, one of the first to write at length in English about Scandinavian law, as a spokesperson for all of Scandinavia, because they cannot follow the internal Scandinavian debates. But it seems that the relatively coherent Scandinavian identity in law and society is used as a strategic argument to fight off certain influences from Europe (or to propose alternatives for European law). Wilhelmsson realizes the strategic use of such proclamations of homogeneity when, in talking of Germany, he refers to 'the homogeneity of (the dominating perceptions) of society. ${ }^{85}$ Claims for the homogeneity of Nordic society may be similar: dominating perceptions invoked for strategic reasons, not actual empirical truths.

\section{b) Pluralism and systems of law}

This last insight suggests a problem with another of Wilhelmsson's claims about legal pluralism. I refer to his claim that pluralistic societies make pluralistic law necessary and unavoidable - or, the flipside, that systematic and monist law is possible only for homogenous societies. This is a frequently made argument in private law debates, but I think it either rests on an error or is at least too simplistic. ${ }^{86}$

Consider Wilhelmsson's claim that the systematic BGB was possible in the $19^{\text {th }}$ century only because society was largely homogeneous, both in its values and in its setup. This historical assumption is hardly tenable: German $19^{\text {th }}$ society was deeply fragmented..$^{87}$ Political views ranged from far more extreme edges than they do today. Society was relatively stratified, and if the $19^{\text {th }}$ century was the century of the bourgeoise, then the pleas of the working class were already growing louder, and their exclusion from the new BGB was already a ground for its criticism. ${ }^{88}$ If Wilhelmsson invokes Wieacker for his claim of societal homogeneity, ${ }^{89}$ he must misunderstand Wieacker, who points out explicily, though elsewhere, 'that the BGB tried to reconcile several different value-systems which nineteenth century German society had allowed to coexist witout coalescing; it is not the mouthpiece of a united social and political movement. ${ }^{90}$

85 T Wilhelmsson, 'Ethical pluralism' (supra note 71) $121 .$.

${ }^{86} \mathrm{I}$ am hoping to work these points out in more detail in a separate paper.

87 The classical work is HU Wehler. Deutsche Gesellschaftsgeschichte, Vol 3 - Von der 'Deutschen Doppelrevolution' bis zum Beginn des Ersten Weltkrieges 1849-1914 (2d ed. 2007); cf. also T Nipperdey, Deutsche Geschichte 1800-1918 (3 Vols., pb. ed. 1998).

88 T Repgen, Die soziale Aufgabe des Privatrechts. Eine Grundfrage in Wissenschaft und Kodifikation am Ende des 19. Jahrhunderts (2001).

${ }^{89} \mathrm{~F}$ Wieacker, Industriegesellschaft und Privatrechtsordnung (1974). Wieacker's views on the relatively liberal character of the BGB have been criticized by J Rückert, 'Das Bürgerliche Gesetzbuch - ein Gesetzbuch ohne Chance?' in Juristenzeitung (2003), 749.

${ }^{90} \mathrm{~F}$ Wieacker, A History of Private Law in Europe (Clarendon Press 1995) 380 
In fact, the German history suggests the exact opposite of Wilhelmsson's claim might be true: a systematic and technical private law may be especially appropriate for a pluralistic society. ${ }^{91}$ The reason is that technical law can translate otherwise unsolvable substantive disputes into solvable technical ones ${ }^{92}$ Substantive incommensurability of plural values is thus overcome in a legal system that guarantees internal coherence as an alternative.

This may or may not be true. It is certainly the case, that the more regulatory law of the $20^{\text {th }}$ century has created a law that is more fragmented, and this may be a sign of pluralism. The point here is that political and societal pluralism is different from legal pluralism, and one does not immediately translate into the other.

\section{c) Irritants}

A third point, however, may be the most important one. Recall how Legrand and Smits dealt with the possibility of legal systems influencing each other. Legrand opposed such influence; Smits celebrated it as a welcome consequence of regulatory competition and free party choice of law. Wilhelmsson does not want to protect national law from Europe (as Legrand does), but neither is he willing to leave interactions between legal systems to a market (as Smits does). Instead, he suggests a careful calibration:

'Solutions cannot be picked out here and there, without strict analysis of their social and cultural background. In a transnationally-oriented legal research which makes use of the fragmentation of law it s not a question of an arbitrary flow of transplants from one place to another, but of finding suitable legal irritants to develop one's own legal surroundings'. ${ }^{93}$

This reference to Teubner's concept of legal irritants is interesting. ${ }^{94}$ Unlike Wilhelmsson, Teubner focuses less on the active choice by the law reformer and more on the internal reactions of legal systems to irritations. And indeed, from his systems theoretical perspective, the idea of actively picking proper irritants seems somewhat paradoxical: If a legal system picks what it wants to be irritated by, then, because it can already predicts what will happen, that is by definition no longer an irritation - in the same way in which we cannot tickle ourselves. ${ }^{95}$

It may be that what Wilhelmsson has in mind is less the reformer in the national system deciding on what to be irritated by, and more the superior governor - say,

\footnotetext{
91 Thus eg E Denninger, 'Recht und rechtliche Verfahren als Klammer in einer multikulturellen Gesellschaft' in RM Kiesow et al (eds), Summa. Dieter Simon zum 70. Geburtstag (Klostermann, 2005), 117.

92 See for this attractive feature of technique K Knop et al (supra note 37) $642 \mathrm{ff}$. 93 T Wilhelmsson, 'Private Law in the EU: Harmonised or Fragmented Europeanization?' (2002) 1 European Review on Private Law, 94. 94 G Teubner, 'Legal Irritants: Good Faith in British Law or How Unifying Law Ends Up in New Divergences' (1998) 61 Modern Law Review 11.

95 PM Bays et al, 'Attenuation of Self-Generated Tactile Sensations Is Predictive, not Postdictive’ (2006) PLoS Biol 4(2): e28. doi:10.1371/journal.pbio.0040028.
} 
the European Commission - deciding how to irritate individual legal systems. In this context, of course, strict analysis of social and cultural background are necessary (though frequently ignored). ${ }^{96}$ But if this is a pluralist perspective, it is at best one of weak legal pluralism: a pluralism that exists due to the recognition of the whole, which in this case is not the state but something functionally similar, the European Union. Ultimately, it appears, Wilhelmsson also shies away from taking the last step towards adopting a true pluralism with no hierarchically superior institution to order and structure it.

\section{VI.Concluding Remarks}

It turns out that none of the three theories discussed here is an actual theory of legal pluralism. Legrand's pluralism is a communitarianism without significant interactions between the separate legal orders he has in mind. Smits proposes a real plurality of interacting legal orders, but then leaves untouched what is perhaps the central issue of legal pluralism, namely mandatory rules,. Wilhelmsson, finally, comes closest to an actual concept of pluralism, but oscillates between ideas of fragmentation and homogeneity, and flirts with regulatory ordering of the pluralism. An actual theory of European private law pluralism is still lacking.

And it may not be forthcoming. After all, all three concepts of legal pluralism are sharply different, but all have several traits in common, too, that may be characteristic of the European debate.

A first commonality is that, when using the idea of legal pluralism, all three authors focus almost exclusively on the idea of a plurality of (formal) legal systems - in particular, national legal systems -, and ignore the second important aspect of legal pluralism, namely the idea of privately created law. This is not to say that ideas about society are absent from the proposals: Legrand conceptualizes laws as mirrors of society; Smits suggests that choice of law is a way to opt out of culture; Wilhelmsson suggests that the plurality of society makes plural legal systems necessary. But in all these concepts, society is a cause for the development of the legal system, not a creator of law on its own. In the end, what all of them focus on as their starting point, is formalized law. This is representative of most debates on European private law more generally.

A second commonality is that none of the three authors here settles for a 'strong' legal pluralism. Wilhelmsson and Smits both assume a superior lawmaker: Wilhelmsson's lawmaker decides which irritants will work best; Smits' superior lawmaker sets up a system of choice of law rules that protect mandatory rules from free choice. Legrand alone seems to oppose such a superior lawmaker, but he does appeal to a general ethical position against mutual domination and influence between legal systems. Here, we see the European preference for 'ordered

${ }^{96} \mathrm{R}$ Michaels, 'Comparative Law by Numbers? Legal Origins Thesis, Doing Business Reports, and the Silence of Traditional Comparative Law' (2009) 57 American Journal of Comparative Law 765, 789-791 with references. 
pluralism'97 Whether viewed as a problem or an opportunity, ultmately, pluralis is something that needs to be regulated.

These are shortcomings vis-à-vis legal pluralism, but not necessarily shortcomings for European private law. The relative neglect of non-state law is not necessarily a bad thing, at least analytically, perhaps even normatively. ${ }^{98}$ The legal pluralism debate has always struggled with the distinction of law and non-law. That may not be a problem for sociological and anthropological accounts, but it does become a problem for debates about law reform.

I have more doubts about the perceived need for an ordered, weak, as opposed to a strong legal pluralism. But in discussions about law reform, a purely sociological perspective as is inherent in traditional concepts of strong legal pluralism, may be inadequate. It may leave reform to technocractic law reformers who may want to implement German-style Codes without sensitivity to the issues the three authors here raise. To engage in law reform debates (as do all three authors), one must enagage in legal discourse. A sociological legal pluralism may be informative for this, but not necessarily conducive to proper legal solutions.

Although these theories are not truly pluralist, we learn something about European private law from each of them. But do we also learn something about legal pluralism, and its adequacy for European private law? The fact that all existing pluralist theories of European private law fail, at least as theories, does not mean that legal pluralism is an intrinsically inappropriate concept for European private law, but it certainly leaves some doubts. Ultimately, it may be that legal pluralism is less adequate than other approaches: The idea of relatively autonomous legal orders does not square well with the interpenetration of European and national law in the European Union. The concept of interlegality, although occasionally invoked also for the relation between European and national law, ${ }^{99}$ may be inferior to recent attempts to reinvigorate conflict of laws. ${ }^{100}$ This suggests that, ultimately, legal pluralism may just have been another terminology with which the ongoing debate on European private law has been led. That may not be so bad.

\footnotetext{
97 M Delmas-Marty, Ordering Pluralism: A Coneptual Framework for Understanding the Transnational Legal World (Hart, 2009). For recent criticism, see Nico Krisch, Beyond Constitutionalism: The Pluralist Structure of Postnational Law (Oxford University Press 2011).

98 S Roberts, 'After government? On Representing Law Without the State' (2005) 68 Modern Law Review, 1.

${ }_{99}$ M Amstutz, 'In-Between Worlds: Marleasing and the Emergence of Interlegality in Legal Reasoning' (2005) 11 European Law Journal 766.

$100 \mathrm{C}$ Joerges and T Ralli (eds.), After Globalisation - New Patterns of Conflict and their Sociological and Legal Re-Constructions (RECON Report No 15, 2011).
} 